\title{
Coma due to Malplaced External Ventricular Drain
}

\section{Yanlı̧̧ Yerleştirilmiş Eksternal Ventriküler Dren Nedeniyle Koma}

\author{
Feng Yih CHAI ${ }^{1}$, Fadzil FARIZAL ${ }^{2}$, Thanabalan JEGAN ${ }^{2}$ \\ 1 University of Kebangsaan Malaysia, Department of Surgery, Cheras, Kuala Lumpur, Malaysia \\ ${ }^{2}$ University of Kebangsaan Malaysia, Division of Neurosurgery, Department of Surgery, Cheras, Kuala Lumpur, Malaysia
}

Corresponding Author: FengYih CHAI / E-mail: chaifengyih@gmail.com

\begin{abstract}
Ventriculostomy or external ventricular drain (EVD) placement by free-hand technique has a high malplacement rate. It is a blind procedure that often requires multiple attempts and revisions. To date, no neurological complication due to EVD malplacement has been reported in the literature. In this report, we present the first case of coma induced by a malplaced EVD and the patient regained consciousness after the drain was adjusted. Our discussion focused on various techniques that can improve the accuracy of EVD insertion. EVD insertion under image guidance provides better accuracy with limited disadvantages. We hypothesized that the patient's coma was due to the mass effect and irritation of the malplaced EVD exerted onto the ventral periaqueductal grey matter and the ascending neurons from upper brainstem.
\end{abstract}

KEYWORDS: Coma, Complications, External ventricular drain, Ventriculostomy, Hydrocephalus

öz

Ventrikülostomi veya serbest eksternal ventriküler dren (EVD) yerleştirmenin yüksek bir yanlış yerleştirme oranı mevcuttur. Bu kör işlem çok sayıda girişim ve revizyon gerektirir. Günümüze kadar EVD yanlış yerleştirilmesi nedeniyle literatürde bir nörolojik komplikasyon bildirilmemiştir. Bu raporda, yanlış yerleştirilen EVD nedeniyle oluşan ilk koma vakasını sunuyoruz. Hastanın bilinci dren ayarlanırken tekrar yerine gelmiştir. Tartışmamız EVD insersiyonunun doğruluğunu arttırabilecek çeşitli tekniklere odaklanmaktadır. Görüntüleme kılavuzluğu altında EVD insersiyonu daha yüksek doğruluğa sahiptir ve dezavantajları sınırlıdır. Hastanın komasının yanlış yerleştirilen EVD'nin ventral periakuaduktal gri madde ve üst beyin kökünün çıkan nöronları üzerinde oluşturduğu kitle etkisi ve irritasyon sonucu oluştuğunu düşünmekteyiz.

ANAHTAR SÖZCÜKLER: Koma, Komplikasyonlar, Eksternal ventriküler dren, Ventrikülostomi, Hidrosefali

\section{INTRODUCTION}

Ventriculostomy or external ventricular drain (EVD) placement is a vital component of neurosurgical care. It is one of the most common life-saving emergency neurosurgery performed to divert cerebrospinal fluid (CSF) flow, to relieve and to measure intracranial pressure. To date, no neurological complication arises from EVD insertion has been reported. Here, we described a man who developed coma due to a malplaced EVD and regained consciousness after the drain was adjusted.

\section{CASE REPORT}

A right-handed, 58-years-old male with no known medical illness was admitted to our hospital with sudden onset of reduced consciousness, headache and hypertension. On arrival, his GCS was 12/15 (E2V4M6), blood pressure was $172 / 111 \mathrm{~mm} \mathrm{Hg}$, pulse was 72 beats/min, respiratory rate 20 breaths/min and temperature was $38.0{ }^{\circ} \mathrm{C}$. His pupils were $3 \mathrm{~mm}$ bilaterally, equal and reactive to light. His blood investigations were normal. His computed tomography (CT) brain scan revealed a diffuse subarachnoid haemorrhage and obstructive hydrocephalus. An emergency right frontal EVD (External CSF Drainage System, Surgiwear, India) was inserted with free-hand technique to relieve the intracranial pressure. It was an uneventful procedure performed by a senior surgical trainee.
Ten hours after the surgery, patient remained unconscious with GCS of 3/15. On review, his blood pressure was 145/90 $\mathrm{mm} \mathrm{Hg}$, pulse was 80 beats/min, respiratory rate was 20 breaths/min, temperature was $37.5^{\circ} \mathrm{C}$, oxygen saturation was $99 \%$ under room air and random blood sugar was $7.1 \mathrm{mmol} / \mathrm{L}$. His pupils were $3 \mathrm{~mm}$ bilaterally, equal and reactive to light. Repeated blood investigations after the surgery were normal. CT brain was repeated promptly and showed no new lesion but the tip of the EVD was inserted too deep and located at the fourth ventricle (Figure 1A-D).

Although the EVD was draining well, it was revised by pulling out $3 \mathrm{~cm}$. Subsequently, the patient's consciousness improved greatly. One hour after the adjustment, his GCS improved to 14/15 (E3V5M6).

\section{DISCUSSION}

Commonly, EVD is inserted with free-hand technique using well-defined anatomical landmarks - Kocher's point, the ipsilateral medial canthus on the coronal plane and the external acoustic meatus on the sagittal plane, to direct the catheter insertion $(8,10)$. The ideal location of EVD tip is the ipsilateral frontal horn of the lateral ventricle near the foramen of Monro. Intraoperatively, surgeons consider the tip of EVD is in place by establishing the free flow of CSF from the distal end of EVD (10). It is a blind, inaccurate and highly 


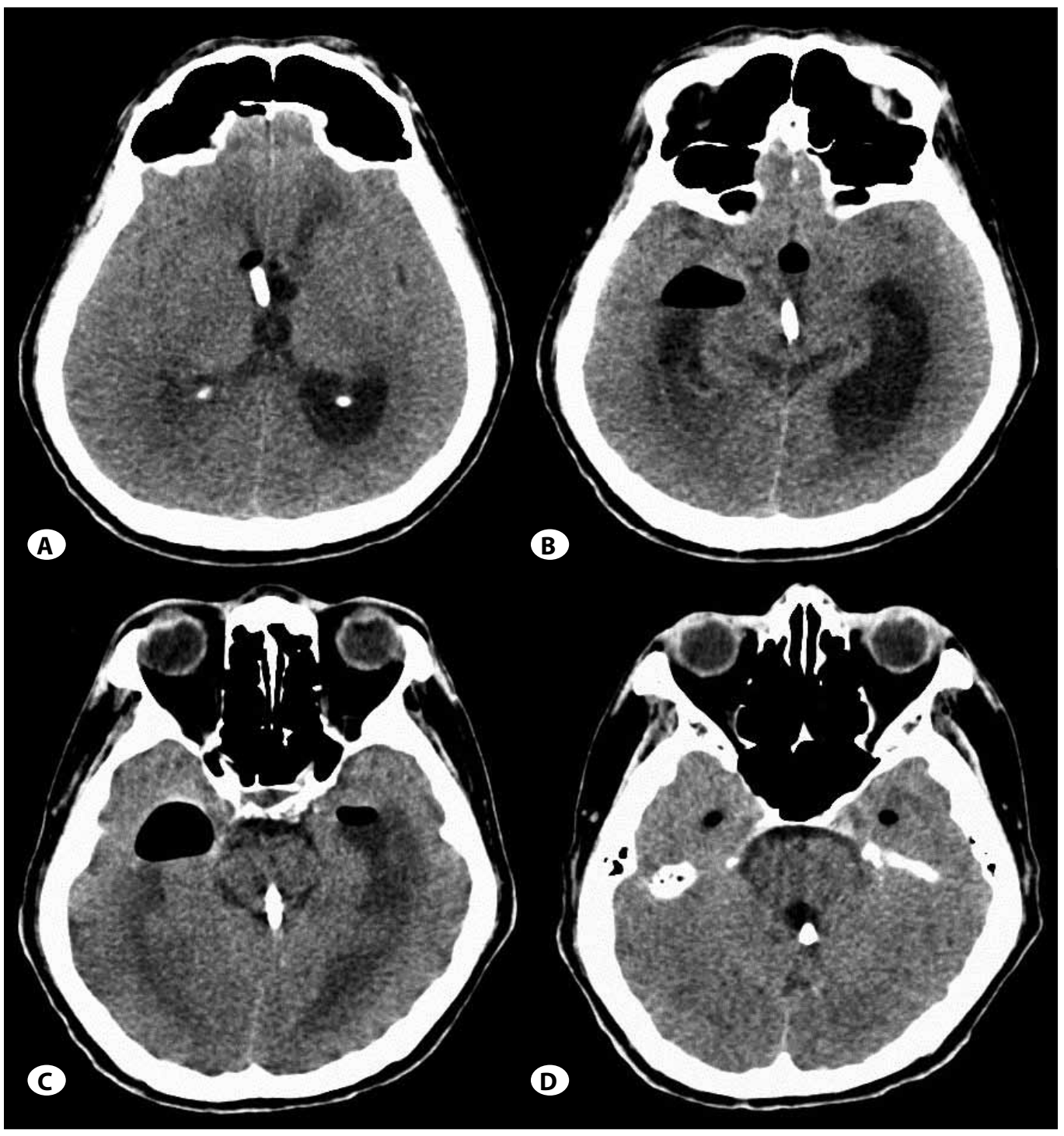

Figure 1: Axial computed tomographic scan showing the external ventricular drain passing through the third ventricle $(\mathbf{A})$ and cerebral aqueduct $(\mathbf{B}, \mathbf{C})$ with its tip at the fourth ventricle (D). invasive procedure. As much as 3 out of 5 EVD insertions were not in place and required multiple passes or revisions $(8,10)$. Factors such as distorted brain anatomy and slit-like ventricle, but not the experience of the surgeon, are associated with EVD malplacement $(3,10)$.

Many techniques have been developed in to improve the success rate and accuracy of EVD placement. A specially designed instrument, i.e. Ghajar Guide (Neurodynamics, Inc., New York, NY), was developed to guide the ventriculostomy perpendicular to the plane tangent to the calvarium at the burr hole. In a prospective trial, O'Leary et al. showed that the use of Ghajar guide in EVD placement was more accurate than without the guide in terms of distance foramen of Monro (3.7 $\pm 5.7 \mathrm{~mm}$ vs. $9.8 \pm 6.3 \mathrm{~mm}$ ) (6). However, the guide is only able to angle the EVD insertion at a perpendicular angle to the calvarium and is not useful in patients with abnormal brain anatomy (10).
In order to save time and to overcome the need of repeated operating theatre visits, percutaneous CT-controlled ventriculostomy (PCV) has been developed. In this technique, after the initial CT brain was acquired, the EVD will be placed in the $C T$ imaging room via aseptic technique and a second CT will be performed immediately to confirm the EVD's position. Comparing the time needed from initial CT scan until the intervention was completed, Krötz et al. showed that the time needed was significantly shorter in the PCV group when compared to the conventional method $(69 \pm 34$ min vs. $138 \pm 34 \mathrm{~min}$ ) (4). Nonetheless, its use is limited by the need of special set up and aseptic environment in the CT imaging room to optimise the surgery.

Along the idea of using image to assist neurosurgery, image guidance system has been developed. It utilises preoperatively acquired $\mathrm{CT}$ or magnetic resonance (MRI) images to generate $3 \mathrm{D}$ multiplanar image intraoperatively 
to guide the EVD placement. The malplacement rate and complication rate was significantly reduced $(2,10)$. It is particularly useful in patients with distorted anatomy and slit ventricle where the system is able to guide the direction and depth of EVD insertion. This technique requires $3 \mathrm{~mm} \mathrm{CT}$ brain data set or MRI images and an image guidance system in operating theatre. Hence, it maybe more time consuming compared to the free-hand technique (2). However, the time consumed may be compensated by the time gained by reducing the number of passes, which might also reduce brain injury (10). Although image-guided EVD placement may be the most efficient and accurate EVD placement technique available, its use is limited by the less than ideal resources in certain underdeveloped or developing countries. Besides, dynamic neuroanatomy changes in certain pathology, i.e. hydrocephalus with expanding intracerebral haemorrhage, may produce discrepancy in the anatomy seen in the initial CT and causes EVD placement malplacement.

Recently, Phillips et al. described the use of ultrasoundguided EVD insertion at the bedside in patients with dynamic neuropathology (7). His technique required a larger burr hole to allow the transducer to be placed onto the dura mater. It provided real-time information for the surgeon to modify the ventriculostomy trajectory according to the patient's distorted and dynamic intracranial anatomy. Although this technique may require some training, it is valuable in the setting where $\mathrm{CT}$ or MRI neuronavigation is unavailable. A prospective study is needed to assess its safety and practicality.

The EVD malplacement rate is reported ranging from $12.3 \%$ to $60.1 \%(8,10)$. Third ventricle, body of lateral ventricle, subarachnoid space, contralateral frontal horn and brain parenchyma are the common locations of the tip of a malplaced EVD. Among these, $19.2 \%$ to $61.9 \%$ malplaced EVD required revision. Of 157 malplaced EVD, there were no known neurological complications reported $(3,8,10)$. To our best knowledge, our patient who developed a reversible coma is the first reported neurological complication due to a malplaced EVD.

The normal calibre of the adult cerebral aqueduct varies from $0.5 \mathrm{~mm}$ to $2.84 \mathrm{~mm}$ (1). The EVD catheter we used has an outer diameter of $2.5 \mathrm{~mm}$. It travelled through the lateral and third ventricles into the cerebral aqueduct with its tip in the fourth ventricle. We hypothesized that the patient's coma was due to the mass effect and irritation of the malplaced EVD exerted onto the ventral periaqueductal grey matter and the ascending neurons from upper brainstem which both has important role in the ascending reticular activating system that promotes wakefulness $(5,9)$. The mass effect might have induced dysfunction of the system and caused the coma. Therefore, when the EVD was adjusted and the mass effect was removed, the patient was able to regain his consciousness.

In conclusion, free-hand insertion of EVD can cause rare but significant neurologic complication. It is a blind and inaccurate procedure. Its significant malplacement rate causes inefficient use of resources and induces morbidity to our patients. Image-guided EVD insertion may be a safer and more efficient approach.

\section{REFERENCES}

1. Flyger $\mathrm{G}, \mathrm{Hjelmquist} \mathrm{U}$ : Normal variations in the caliber of the human cerebral aqueduct. Anat Rec 127:151-162, 1957

2. Hayhurst $C$, Byrne P, Eldridge PR, Mallucci CL: Application of electromagnetic technology to neuronavigation: A revolution in image-guided neurosurgery. J Neurosurg 111:1179-1184, 2009

3. Kakarla UK, Chang SW, Theodore N, Spetzler RF, Kim LJ: Safety and accuracy of bedside external ventricular drain placement. Neurosurgery 63:ONS162-ONS166, 2008

4. Krötz M, Linsenmaier U, Kanz KG, Pfeifer KJ, Mutschler W, Reiser M: Evaluation of minimally invasive percutaneous CT-controlled ventriculostomy in patients with severe head trauma. Eur Radiol 14:227-233, 2004

5. Lu J, Jhou TC, Saper CB: Identification of wake-active dopaminergic neurons in the ventral periaqueductal gray matter. J Neurosci 26:193-202, 2006

6. O'Leary ST, Kole MK, Hoover DA, Hysell SE, Thomas A, Shaffrey $\mathrm{Cl}$ : Efficacy of the Ghajar Guide revisited: A prospective study. J Neurosurg 92:801-803, 2000

7. Phillips SB, Gates M, Krishnamurthy S: Strategic placement of bedside ventriculostomies using ultrasound image guidance: Report of three Cases. Neurocrit Care DOI: 10.1007/s12028011-9571-2, 2011

8. Saladino A, White JB, Wijdicks EFM, Lanzino G: Malplacement of ventricular catheters by neurosurgeons: A single institution experience. Neurocrit Care 10:248-252, 2009

9. Schwartz JRL, Roth T: Neurophysiology of sleep and wakefulness: Basic science and clinical implications. Curr Neuropharmacol 6:367-378, 2008

10. Toma AK, Camp S, Watkins LD, Grieve J, Kitchen ND: External ventricular drain insertion accuracy: Is there a need for change in practice? Neurosurgery 65:1 197-1200, 2009 